\title{
呼吸による人体ウイルス感染のシミュレーション*
}

\author{
山本 俊 昭*1, 梁昌 浩*2, 小田原 聡*2 \\ 安田龍 介 $^{* 1}$, 大久保 雅章*1, 黒木智 之*1
}

\section{Simulation of Human Virus Infection Accompanied by Inhalation}

Toshiaki YAMAMOTO*3, Masahiro RYO, Satoshi ODAHARA, Ryusuke YASUDA, Masaaki OKUBO and Tomoyuki KUROKI

${ }^{* 3}$ Department of Mechanical Engineering, Osaka Prefecture University,

1-1 Gakuen-cho, Sakai-shi, Osaka, 599-8531 Japan

\begin{abstract}
Severe Acute Respiratory Syndrome (SARS) and virus infection from animals became as a world-shaking happening and people from all over the world are concemed as human safety. The numerical simulation was carried out to help understanding how close and how long the virus can reach the human through normal inhalation and exhalation. Two-dimensional numerical simulations were carried out to solve a time-dependent airflows and particle dynamics in the vicinity of human face accompanied by inhalation by viewing both top and side of the human body. The time dependent virus concentrations were determined. The time to reach humans, the distribution of the particles, and the amount of virus inhaled were evaluated as a parameter of the initial virus location, breathing angle, and the direction of the airflows.
\end{abstract}

Key Words : Computational Fluid Dynamics, SARS, Virus, Inhalation, Breathing, Simulation

\section{1. 精 諭}

近年, 空気感染とされる SARS や鳥インフルエン ザなどウイルスを保有する動物の問題が突然発生し, 大きな社会的問題となっている(囘. 浮遊ウイルスや 有害大気污染物質が存在する環境では, 病院内で医者 や看護師と病人との感染，ウイルス等を保有する動物 からの感染, ディーゼル排ガスのススやタバコ煙が呼 吸によって人間の体内に吸引される状況が考えられ， 時間と量, 顔からウイルスまでの距離との相関性を把 握することは重要な問題である.

本研究では，大気中に浮遊しているウイルスを対 象として，呼吸を伴う人体の颜からウイルス初期位置 までの距離を変化させ, 体内にどのくらいの時間がか かって吸入されるか，及び, 顔前面のウイルスが人間 の体内に入るまでの挙動，つまり䈨度分布や吸入量の 経時変化を数值シミュレーションにより求めた. これ までの研究として呼吸を伴う顔周りの研究はきわめて

* 原稿受付 2004 年 8 月 23 日.

*1 正員, 大阪府立大学大学院工学研究科 $(599-8531$ 堺市学 園町 1-1).

${ }^{* 2}$ 大阪府立大学大学院工学研究科.

E-mail : yamamoto@me.osakafu-u.ac.jp

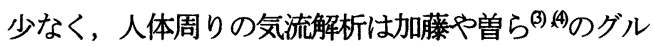
ープで行われている. アメリカ環境庁 (EPA) 中央研 究所では室内環境下でどの程度の微粒子, ガス状污染 物質が体内に取り込まれるかの測定を胸にサンプラー を取り付け, 通常の生活をすることによって測定を行 っている. 我々はその研究の一環として, 彼らの持つ データと日常生活で呼吸を伴う人間との相関性を評価 する目的で 3 年前から呼吸を伴う顔近傍の微粒子挙動 現象モデルの開発を始めた. 呼吸を伴う顔近傍の微粒 子現象は複雑な三次元的な取扱いが必要ではあるが, 解析が非常に複雑でかつこのような研究は世界的に見 ても非常に少ないため, まず手始めに二次元解析から 始め, このような解析が可能かどうかを試みた。

シミュレーションでは，人間頭部を含む地上と平 行な平面と, 人間断面の双方から二次元的に取扱い, 番での呼吸条件を与え，二次元乱流数值解析により流 れ場の計算を行った. 粒子の挙動は流線に沿って挙動 する質量のない仮想粒子が顔面前方に一様に存在する 設定で計算を行い，ウイルスのような $0.1 \mu \mathrm{m}$ 程度の拡 散現象を無視した微粒子挙動として考え, ウイルス到 達時間, 体内吸入量を評価した. 


\section{2. 数 值 解 析}

流れ場の支配方程式は質量保存式（連続の式）， 運動方程式（Navier-Stokesの方程式）で, SIMPLE法 を用いて二次元非定常乱流場として計算した (5-8). 格子点を中心としたコントロールボリュームを考慮 し, その中で支配方程式を積分し，離散化方程式を 立てる方法である. 差分スキームは対流項にハイブ リッド法, 拡散項に二次精度の中心差分を用いた。 時間積分は完全陰解法を用いた(7).

計算領域としては, 図 1 に示すように人閒の顔を 含み, 地上と平行な二次元断面を考慮した. 流体場 の計算領域は $152 \mathrm{~cm} \times 104 \mathrm{~cm}$ とし, 格子間隔を $\Delta \mathrm{x}$ $=\Delta \mathrm{y}=0.4 \mathrm{~cm}$ とし, この領域が外側に遠ざかるにつ れて, 格子間隔を $6 \mathrm{~cm}$ まで増加させる不等間隔格 子を用い, 全体の格子数は $\mathrm{x}$ 方向に $314, \mathrm{y}$ 方向に 142 とし，時間刻みは $\Delta \mathrm{t}=0.005$ 秒で計算を行った。

次に，図 2 に示すような身長 $160 \mathrm{~cm}$ の人間の二 次元断面を考慮し, 計算領域は $260 \mathrm{~cm} \times 250 \mathrm{~cm}$, 詳 細格子間隔を $\Delta \mathrm{x}=\Delta \mathrm{y}=0.4 \mathrm{~cm}$, 人間から外側に遠 ざかるにつれて，格子間隔を増加させる不等間隔格 子を用い, 全体の格子数は $\mathrm{x}$ 方向に $230, \mathrm{y}$ 方向に 336 とし，時間刻みは同様に $\Delta \mathrm{t}=0.005$ 秒として計算 を行った.

境界条件として人体表面境界条件には壁法則（対 数則) (5) (9) (10)を用いた。 流出境界条件は静止流体の 場合, 顔の前後方向は自由流出, 顔の左右方向は周 期境界，地面はノンスリップ条件を用いた。風があ る場合は, 風向に対して下流の境界面は自由流出, 左右方向の境界面は周期境界を用いた。呼吸条件と しては，人間一日 $1000 \mathrm{~L}$ 呼吸すると言われている ので, 平均呼吸回数を $15 \sim 20$ 回, 鼻の面積を $1 \mathrm{~cm}^{2}$ のペアとすると, 鼻の呼吸流速は $0.2 \mathrm{~m} / \mathrm{s}$ （睡眠状 態）と $0.5 \mathrm{~m} / \mathrm{s}$ （通常状態）と選定した.

呼吸モードとして種々のパターンを試みたが，本 稿では吸い込みが 1 秒, 吐き出しが 1 秒, 静止が 1 秒の呼吸パターンを選定した. また, 顔正面方向に 対する呼吸流の角度を呼吸角度 $\theta$ とし， $\theta$ を 0,15 , 30 度に設定した。図 1 の平面二次元の場合, 仮想粒 子初期分布は, 顔前面に幅 $40 \mathrm{~cm}$, 厚さ $10 \mathrm{~cm}$ に粒子 を一様分布させ, 鼻先からの距離を $10 \mathrm{~cm}(\mathrm{~L}=10$ $\mathrm{cm}), 20 \mathrm{~cm}(\mathrm{~L}=20 \mathrm{~cm}), 30 \mathrm{~cm}(\mathrm{~L}=30 \mathrm{~cm}), 40 \mathrm{~cm}$ $(\mathrm{L}=40 \mathrm{~cm})$ と変化させ, 流れ場の速度から仮想粒子 の移動量を求め, 0.005 秒ごとに追跡し， 1 秒ごとの 粒子分布を動画として取り込むことにより経時変化 を求めた。 なお, 仮想粒子は顔表面では付着しない

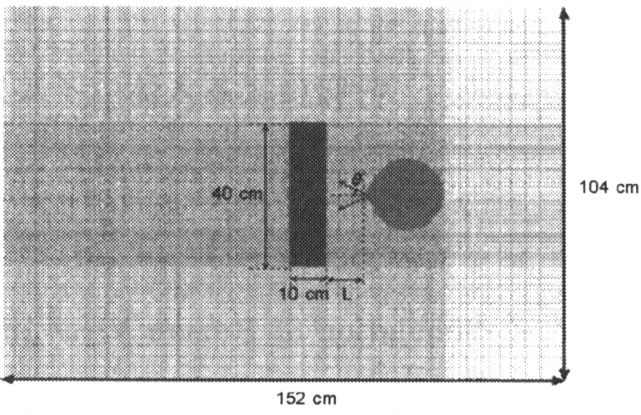

Fig. 1 Computational domain and the selection of grid size for the human plane view

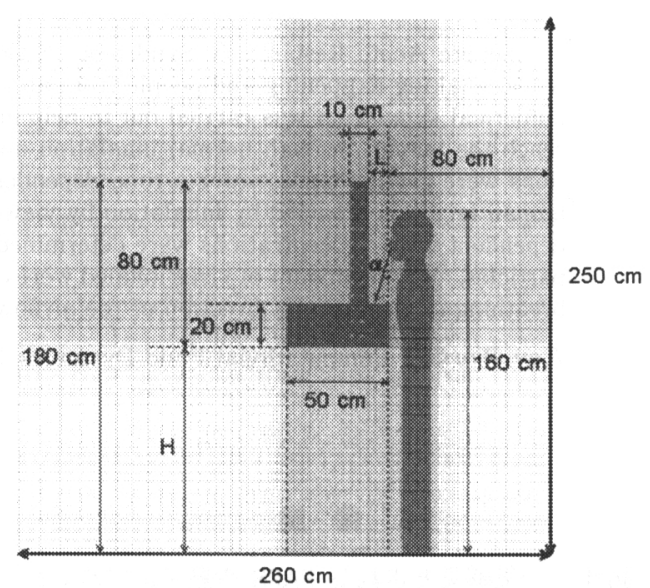

Fig. 2 Computational domain and the selection of grid size for the human cross section view

ように設定し，一旦，鼻に吸入すると粒子が呼吸と ともに体外に流出しないように設定した.

図 2 に示すような人間全体の二次元断面の場合, 仮 想粒子初期条件として幅 $10 \mathrm{~cm}$, 地上高さ $100-180 \mathrm{~cm}$ に粒子を一様分布させ, 鼻先からの距離を $10 \mathrm{~cm}(\mathrm{~L}=10$ $\mathrm{cm}), 20 \mathrm{~cm}(\mathrm{~L}=20 \mathrm{~cm}), 30 \mathrm{~cm}(\mathrm{~L}=30 \mathrm{~cm}), 40 \mathrm{~cm}(\mathrm{~L}=40 \mathrm{~cm})$ と 変化させ, 流れ場の速度から仮想粒子の移動量を求め, 0.005 秒ごとに追跡して 1 秒ごとの動画として取込み, 仮想粒子の挙動を観察した。 なお，地軸に対する呼吸 流の角度を呼吸角度 $\alpha$ とし， $\alpha$ を 15，30 度に設定した。 次に, 高さ方向の影響を評価するために, 初期粒子分 布を横幅 $50 \mathrm{~cm}$, 高さを $20 \mathrm{~cm}$ とし, 高さ方向に $100 \mathrm{~cm}$ $(\mathrm{H}=100 \mathrm{~cm}), 120 \mathrm{~cm}(\mathrm{H}=120 \mathrm{~cm}), 140 \mathrm{~cm}(\mathrm{H}=140 \mathrm{~cm}), 160$ 
$\mathrm{cm}(\mathrm{H}=160 \mathrm{~cm}), 180 \mathrm{~cm}(\mathrm{H}=180 \mathrm{~cm})$ と変化をさせ，60秒閒 の仮想粒子の挙動を計算し, 高さ方向の体内吸入率の 評価を検討した. ここで取り扱う仮想粒子は $0.1 \mu \mathrm{m}$ 程 度の粒子と考え, 微粒子搪散を伴わないウイルスの挙 動と呼ぶこととした.

\section{3. 計 算 結 果}

周辺気体が静止状態時, 鼻の呼吸速度が $0.5 \mathrm{~m} / \mathrm{s}$, 呼 吸角度 $\theta$ を両サイドに 15 度と設定し, 初期ウイルス 分布は顔前面加の距離を $\mathrm{L}=10,20,30,40 \mathrm{~cm}$ と変 化させ，呼吸開始 10 秒後のウイルス分布を図3(a)(d)に 示す． 初期ウイルス分布が $\mathrm{L}=10 \mathrm{~cm}$ の分布から明らか なように，呼吸によりウイルスは鼻前面に押し出され， 顔の側面に拡散し，側面より体内に吸入され，顔前面 に一対の渦流を形成する様子がわかる. ウイルスは呼 吸開始後 10 秒で体内に到達し, 13 秒後には $4 \%$ のウ イルスが体内に吸入され，それ以後，ウイルス分布は 顔前面から離れ体内に吸引されない，顔前面 $\mathrm{L}=20 \mathrm{~cm}$ 以上の場合は渦流を形成する過渡状態を示寸が， $\mathrm{L}=20$ cm以上となると体内に全く吸入されない.

次に，呼吸開始 20 秒後のウイルス分布を図 4(a)-(d) に示寸. $\mathrm{L}=10 \mathrm{~cm}$ と $\mathrm{L}=20 \mathrm{~cm}$ の場合は顔前面に渦流を 形成しているが， L=30 cm， L=40 cm の場合は過渡状態 を示している.これ以上時間が経過しても，いずれの 場合もウイルスは顔前面から離れ, 体内一の吸入は起 こらない. 次に, 呼吸角度 $\theta$ を $0,15,30$ 度と変化さ せ， $\mathrm{L}=20 \mathrm{~cm}$ ，呼吸開始 10 秒後の分布を図 $5(\mathrm{a})(\mathrm{c})$ に示

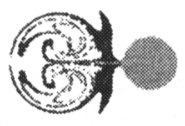

(a) $\mathrm{L}=10 \mathrm{~cm}$
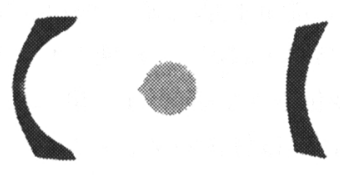

(c) $\mathrm{L}=30 \mathrm{~cm}$

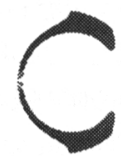

(b) $\mathrm{L}=20 \mathrm{~cm}$

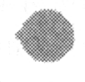

(d) $\mathrm{L}=40 \mathrm{~cm}$

Fig. 3(a)-(d) Virus distribution after $10 \mathrm{~s}$ inhalation/exhalation with a breathing speed of $50 \mathrm{~cm} / \mathrm{s}$ and a breathing angle of 15 degree as a parameter of source distance

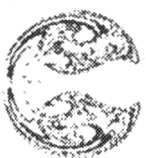

(a) $\mathrm{L}=10 \mathrm{~cm}$

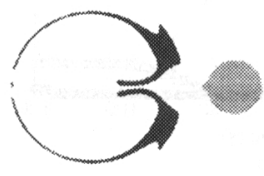

(c) $\mathrm{L}=30 \mathrm{~cm}$

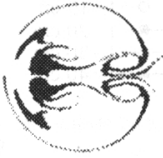

(b) $\mathrm{L}=20 \mathrm{~cm}$

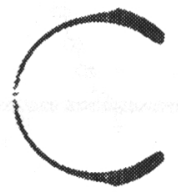

(d) $\mathrm{L}=40 \mathrm{~cm}$
Fig. 4(a)-(d) Virus distribution after 20s inhalation/exhalation with a breathing speed of $50 \mathrm{~cm} / \mathrm{s}$ and a breathing angle of 15 degree as a parameter of source distance

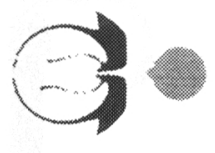

(a) $\theta=0$ degree

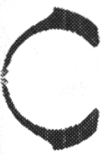

(b) $\theta=20$ degree

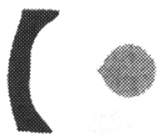

(c) $\theta=30$ degree

Fig. 5(a)-(c) Virus distribution after 10s inhalation/exhalation with a breathing speed of $50 \mathrm{~cm} / \mathrm{s}$ and the breathing angle of 0,15 , and 30 degrees

す. 呼吸開始 10 秒後でウイルス分布は大幅に変わる

が，体内到達時間への影響は少ない。

周辺気体が静止状態時で, 鼻の呼吸速度が $02 \mathrm{~m} / \mathrm{s}$ と選定した場合, 初期ウイルス分布が $\mathrm{L}=10 \mathrm{~cm}$ の時, 図には示されてないが，22秒後には体内に到達し，60 秒後には初期值の $40 \%$ \%ウイルスが体内に吸引され る. 鼻から初期ウイルス分布までの跑離による人体一 の到達時間と吸入量の相関関係を図 6 に示寸，初期ウ イルス分布が $\mathrm{L}=20 \mathrm{~cm}$ の時，体内に到達するまでに 52 


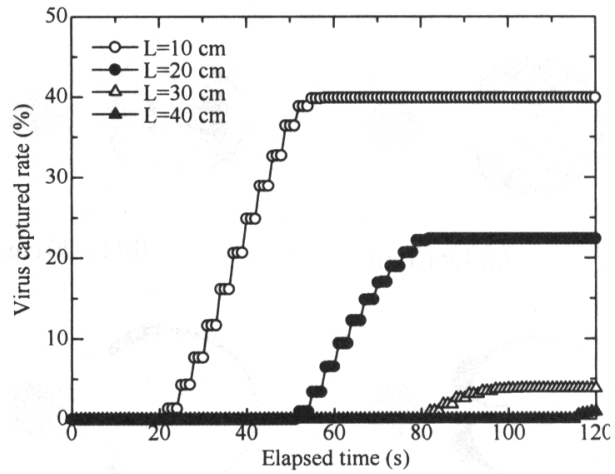

Fig. 6 Virus arrival time and number virus captured with a breathing speed of $20 \mathrm{~cm} / \mathrm{s}$ and a breathing angle of 15 degree as a parameter of source distance
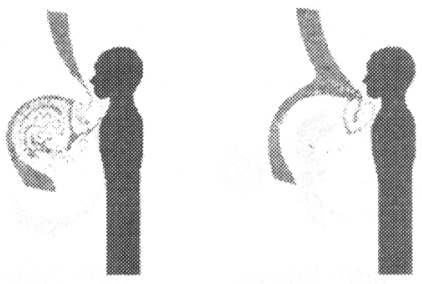

(a) $\mathrm{L}=10 \mathrm{~cm}$

(b) $\mathrm{L}=20 \mathrm{~cm}$
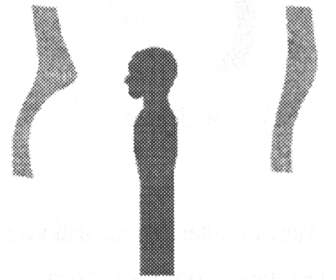

(c) $\mathrm{L}=30 \mathrm{~cm}$

(d) $\mathrm{L}=40 \mathrm{~cm}$

Fig. 7(a)-(d) Virus distribution after $15 \mathrm{~s}$ inhalation /exhalation with a breathing speed of $50 \mathrm{~cm} / \mathrm{s}$ and a breathing angle of 15 degree as a parameter of source distance

秒かかり， $\mathrm{L}=30 \mathrm{~cm}$ と $40 \mathrm{~cm}$ の時は体内に到達するま で 82 秒，116秒功る。.このように，体内到達時間は 呼吸流速に強い影響を受ける。 また，吸入・呼気の呼 吸サイクルの順序を変えてもウイルス分布や到達時間

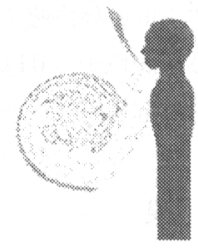

(a) $\mathrm{L}=10 \mathrm{~cm}$

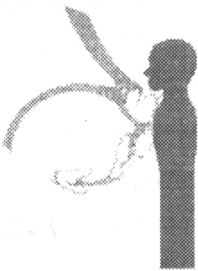

(c) $\mathrm{L}=30 \mathrm{~cm}$

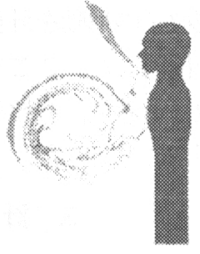

(b) $\mathrm{L}=20 \mathrm{~cm}$

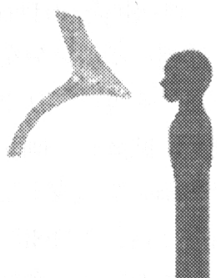

(d) $\mathrm{L}=40 \mathrm{~cm}$
Fig. 8(a)-(d) Virus distribution after 30s inhalation/exhalation with a breathing speed of $50 \mathrm{~cm} / \mathrm{s}$ and a breathing angle of 15 degree as a parameter of source distance

への影響はなかった. さらに，呼吸パターンを Sineカ 一ブ的に変化させても， ウイルス分布には変化が見ら れたが，ウイルス到達時間への影響は少なかった，周 辺気体の風速を $0.02 \mathrm{~m} / \mathrm{s}$ と設定し, 風向は前後横の三 方向を考慮した. この場合, 図には示されていないが, ウイルス分布や体内吸入量は風の影響により大きく変 わり, 横風方向が最大体内吸入量となることがわかっ た(6)

次に，人間を側面から見てシミュレーションを行 った場合, 周辺気体が静止状態で鼻の呼吸流速が 0.5 $\mathrm{m} / \mathrm{s}$, 呼吸角度 $\alpha$ を 15 度と設定し，初期ウイルス分布 と顔からの距離を変化させた場合 $(\mathrm{L}=10,20,30$, $40 \mathrm{~cm})$ で, 呼吸開始後 15 秒後のウイルス分布の結果 を図 7(a)(d)に示す. $\mathrm{L}=10 \mathrm{~cm}$ と $\mathrm{L}=20 \mathrm{~cm}$ の場合はすでに ウイルスは体内に到達しており，図 7(a)(b)に示される ように顔前面下部に顔の 2 倍程度の渦流が時計周りに 形成されている. $\mathrm{L}=30 \mathrm{~cm}$ と $\mathrm{L}=40 \mathrm{~cm}$ の場合, 図 7(c)(d) に示されるように過渡状態で，これ以上時間経過して も体内には到達しない. 図 8(a)(d)に呼吸開始 30 秒後 の $\mathrm{L}=10,20,30,40 \mathrm{~cm}$ におけるウイルス分布を示す. ウ イルスの体内吸入は顔に沿って主に顔上部から吸入す 


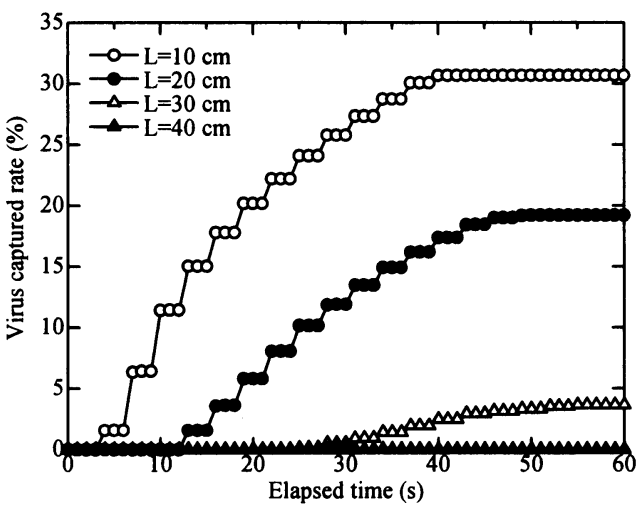

Fig. 9 Virus captured rate and time to reach human as a parameter of source distance

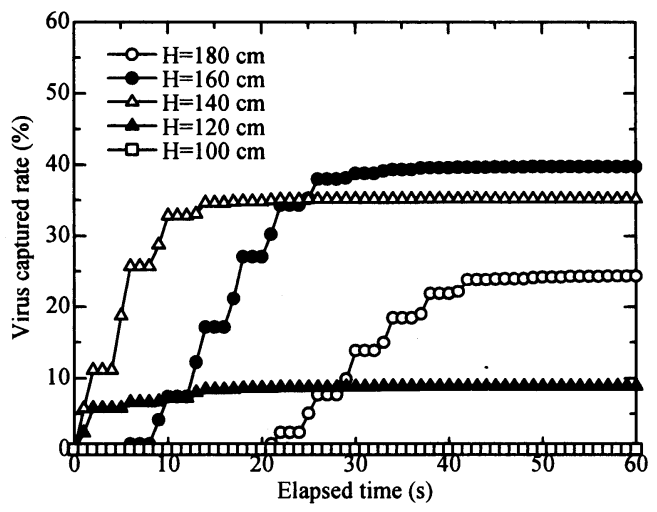

Fig. 10 Effect of height of source on time to reach human and virus captured rate

Table 1. Time to reach human, vinus inhalation time, time to reach saturation, and virus captured rate for various source distance as a parameter of breathing angle

\begin{tabular}{cccccc}
\hline $\begin{array}{c}\text { Degree } \\
(\mathrm{C})\end{array}$ & $\begin{array}{c}\mathrm{L} \\
(\mathrm{cm})\end{array}$ & $\begin{array}{c}\text { Virus arrival time } \\
(\mathrm{s})\end{array}$ & $\begin{array}{c}\text { Time to reach } \\
\text { saturation(s) }\end{array}$ & $\begin{array}{c}\text { Virus inhalation time } \\
(\mathrm{s})\end{array}$ & $\begin{array}{c}\text { Virus captured rate } \\
(\%)\end{array}$ \\
\hline \multirow{2}{*}{30} & 10 & 4 & 40 & 36 & 30.7 \\
\cline { 2 - 7 } & 20 & 13 & 50 & 37 & 19.2 \\
\hline \multirow{2}{*}{15} & 10 & 4 & 40 & 36 & 32.6 \\
\cline { 2 - 7 } & 20 & 10 & 46 & 36 & 20.4 \\
\hline
\end{tabular}

ることがわかる. 顔前面で生ずる渦流はさらに大きく 成長していることもわかる.

ウイルス分布と鼻からの距離による人体到着時間 と吸入量の相関関係を図 9 に示す．初期ウイルス分布 が $\mathrm{L}=10 \mathrm{~cm}$ のとき, 4 秒後にはウイルスが体内に到達 し，40秒後には31\%のウイルスが体内に吸入され，そ の後は体内に吸引されない. $\mathrm{L}=20 \mathrm{~cm}$ の場合, 13 秒後 に体内に到着し，50秒後には 19\%のウイルスが体内に 到達し, その後は体内に吸引されず定常状態となる.

$\mathrm{L}=30 \mathrm{~cm}$ の場合, 26 秒後には体内に到達し，56 秒後に 3.7\%のウイルスが体内に到達し, その後は体内に吸引 されない. $\mathrm{L}=40 \mathrm{~cm}$ の場合, ウイルスは全く体内に吸 引されないことがわかる.

呼吸角度 $\alpha$ を 15,30 度と変化させた場合, 吸入開 始時間, 吸入終了時間, 吸入時間, 初期ウイルス量に 対する体内吸入率を表 1 に示す. 表から明らかなよう に，呼吸角度による吸入開始時間や体内吸入率一の影 響は少ない。
次に，地上からの高さの影響をみるために，初期ウ イルス分布として図 2 に示すように顔からの横幅 50 $\mathrm{cm}$, 高さ $20 \mathrm{~cm}$ とし, 高さ方向に $\mathrm{H}=100 \mathrm{~cm}, \mathrm{H}=120 \mathrm{~cm}$, $\mathrm{H}=140 \mathrm{~cm}, \mathrm{H}=160 \mathrm{~cm} ; \mathrm{H}=180 \mathrm{~cm}$ と変化をさせた時の体 内吸入率を評価した. 同様に 60 秒間のウイルス挙動 計算を行い, その結果を図 10 に示す. $\mathrm{H}=140 \mathrm{~cm}$ $(140-160 \mathrm{~cm})$ の高さのウイルス分布が直ちに体内に 到達し，35\%のウイルスが体内に到達した. 次に, 初 期ウイルス分布が $\mathrm{H}=160 \mathrm{~cm}(160-180 \mathrm{~cm})$ の時, 初期 分布から 6 秒で到達し $H 140 \mathrm{~cm}$ より多く $40 \%$ 年体内 に吸入された. $\mathrm{H}=180 \mathrm{~cm}(180-200 \mathrm{~cm})$ の時は 20 秒経 過後体内に吸入され，24\%が体内に吸入された. $\mathrm{H}=120 \mathrm{~cm}(120-140 \mathrm{~cm})$ では直ちに体内に到達するが, 体内吸入量は $9 \%$ となった. $\mathrm{H}=100 \mathrm{~cm}(100-120 \mathrm{~cm})$ 以 下ではウイルスの体内吸入は起こらなかった.

顔を含む二次元平面と, 人体断面の二次元のウイ ルス到達時間と体内吸入量の定量的解析を行ってきた が, 結果の定量的評価には実験検証と, 外気温度や体 
温を含むより現実的な三次元モデルとの比較が必要で ある. しかしながら，二次元両断面の計算からもある 程度の粒子の挙動，定性的評価が把握できる.

我々は現在，外気温度や体温を含むより現実的な 三次元モデルの開発を進めている. 体内に吸入された 微粒子, 污染ガスの体内沈着モデル (Lung Deposition Model）はすでに多くの研究がなされており, 最終的 にはこの Lung Deposition Model と我々のモデルとを結合 させ，屋内環境が健康へどのように影響を及ぼすかと いう人間環境モデル (Human Exposure Model) へと拡張 させていく.

\section{4. 結 論}

大気中に浮遊しているウイルスを対象とし, 発生源 と呼吸を伴う人体との距離を変化させ, 体内への到達 時間, ウイルス挙動, 濃度分布, 人体への吸入量の経 時変化を求める二次元乱流数值シミュレーションを行 うことに成功した. シミュレーションでは顔を含む二 次元平面と人体断面双方から評価を行い, 呼吸速度, 発生源と人体との距離，呼吸角度，周辺気流速度，高 さ方向による影響を求めた. 通常の呼吸速度 $50 \mathrm{~cm} / \mathrm{s}$ 程度では, 顔前面で顔の 2 3 倍の渦流を形成し, 初期 ウイルス分布が $10 \mathrm{~cm}$ では 4 秒程度, $20 \mathrm{~cm}$ では 10-14 秒で体内に到達寸る. 人体到達時間は鼻からの距離に 比例し，吸入は顔両側面，また，上部から吸入される ことがわかった.このようなシミュレーションがウイ
ルス等を保有する人間，動物との距離の決定，ディー ゼル排ガスやタバコ煙等の污染源と人間をとりまく健 康に及ぼすシミュレーションに展開することを期待し ている.

\section{文 献}

(1) Peiris, J.S.M, etal,Lanot, 361,(2003), 1319-1325.

(2) WHO, Weekly Epidemiological Recard, 79, (2004), 65-76.

(3) 加藤・ほか 2 名, 日本建筑学会計画系論文集, 509 , (1998),21-26.

(4) 曾・ほか 2 名, 日本建築学会計画系論文集 505 , (1998), 31-38.

(5) 吉沢 - ほ力 5 名, 乱流解析, 東京大学出版会, (1995), 166-167.

(6) 山本・ほか 4名, 第20回エアロゾル科学・技術 研究討論会講演論文集, (2002), $159-160$.

(7) 香月・中山, 熱流動の数值シミュレーション,森 北出版, (1990), 35-54.

(8) Paraka, S.V, Numerical Heat Transfer and Fluid Flow, MoGraw-Hill, (1980), 113-130.

(9) 荒川, 数值流体工学, 東京大学出版会, (1993), 102105.

(10) 村上・ほか2名,生産研究,41,(1989),3-9. 